J. Great Lakes Res. 34:54-71

Internat. Assoc. Great Lakes Res., 2008

\title{
Interaction between Macroinvertebrate Abundance and Habitat Use by Diving Ducks during Winter on Northeastern Lake Ontario
}

\author{
Michael L. Schummer ${ }^{1, \dagger,}$, Scott A. Petrie ${ }^{2}$, and Robert C. Bailey ${ }^{3}$ \\ ${ }^{1}$ Department of Biology \\ University of Western Ontario \\ London, Ontario N6A $5 B 7$ \\ ${ }^{2}$ Long Point Waterfowl and Wetlands Research Fund \\ Bird Studies Canada \\ P. O. Box 160 \\ Port Rowan, Ontario NOE 1 WO \\ ${ }^{3}$ Department of Biology \\ University of Western Ontario \\ London, Ontario N6A 5B7
}

\begin{abstract}
Although numbers of buffleheads (Bucephala albeola), common goldeneyes (Bucephala clangula) and long-tailed ducks (Clangula hyemalis) over-wintering on Lake Ontario have increased substantially over the past two decades, factors influencing habitat use and the potential for competition have not been investigated. The purpose of this study was to determine the relationship between prey availability and community structure of diving ducks during winter on northeastern Lake Ontario. Benthic and nektonic samples collected during fall, winter, and spring 2002-2004 indicated that macroinvertebrate numbers differed by location but generally did not decline throughout winter. Large accumulations of macroinvertebrates, apparently moved by wave action and currents, were documented in nearshore areas. Surveys showed that diving ducks congregated in mixed species flocks within areas of higher food abundance. Mixed species flocks were common in nearshore areas, likely because energydense foods (Amphipoda and Chironomidae) were abundant in the narrow zone of shallow water, close to shore. Although macroinvertebrate numbers likely affected habitat use by diving ducks, birds did not greatly reduce abundance of macroinvertebrates. It is unlikely that exploitative competition was occurring and interference competition appeared below threshold levels that would cause species to spatially segregate. Overall, our results suggest that food availability is not a limiting factor for buffleheads, common goldeneyes, or long-tailed ducks wintering on northeastern Lake Ontario.
\end{abstract}

INDEX WORDS: Habitat use, limiting factors, Lake Ontario, macroinvertebrate, waterfowl, winter.

\section{INTRODUCTION}

During winter, diving ducks forage heavily on benthic macroinvertebrates (Nilsson 1972, Stott and Olson 1973, Bellrose 1980, Jones and Drobney 1986, Poulton et al. 2002). Although diving ducks often select areas of high macroinvertebrate abundance and quality during winter (Nilsson 1972, Stott and Olson 1973, Phillips 1991), they can substantially reduce food resources during that time $(\mathrm{Pe}-$

\footnotetext{
${ }^{*}$ Corresponding author. E-mail: mschummer@cfr.msstate.edu Current address: Department of Wildlife \& Fisheries, Mississippi State University, Box 9690, Mississippi State, MS 39762
}

droli 1981; Suter 1982 a,b,c). For waterfowl wintering at northern latitudes, this relationship should be intensified because food resources decrease throughout winter due to predation by ducks (Pedroli 1981; Suter 1982a,b,c; Marsh 1986; Suter and Van Eerden 1992; Hamilton et al. 1994), productivity of macroinvertebrates is greatly reduced (Thorp and Covich 1991), thermoregulatory costs are relatively high in waterfowl (Owen and Reinecke 1979, Prince 1979, Lima 1986), and food accessibility can be limited by ice coverage (Albright 1981, Jones and Drobney 1986, Suter and Van Eerden 1992, Guillemette et al. 1993, Hamilton et al. 1994). 
Because waterfowl typically congregate near food during winter, potential for competition among sympatric species exists if food resources become limited. Food limitation coupled with strong competition should lead to resource partitioning among sympatric species and is considered a stabilizing mechanism whereby overlap in use of resources is minimized to allow for coexistence (MacArthur and Levins 1967, Schoener 1974, Wiens 1977, Diamond 1978, Arthur 1987, Keddy 1989). However, when food is highly available, resource partitioning between species is no longer necessary (Wiens 1977), thereby enabling sympatric species to congregate and exploit food resources (Horn 1968, Mayr 1970, Cody 1974, Schoener 1974). Therefore, by simultaneously monitoring social interactions among sympatric species and changes in resource availability, effects of food resource abundance on community structure can be investigated.

Numbers of staging and wintering diving ducks increased on the Lower Great Lakes soon after invasion by dreissenid mussels (quagga [Dreissena bugensis] and zebra [D. polymorpha] mussels) and most molluscivorous waterfowl now incorporate these mussels into their diet (Wormington and Leach 1992, Hamilton and Ankney 1994, Custer and Custer 1996, Petrie and Knapton 1999, Mitchell et al. 2000, Ross et al. 2005, Badzinski and Petrie 2006). Although the number of molluscivorous diving ducks over-wintering on the north shore of Lake Ontario substantially increased between the 1980s and 1990s (Petrie and Schummer 2002), little is known about how resource availability influences bird numbers, spatial distributions, or community structure during winter.

Hamilton et al. (1994) and Mitchell et al. (2000) concluded that, while diving ducks could temporarily reduce mussel populations at Lake Erie, longterm effects on mussel populations would be limited because: (1) ice coverage excluded ducks from foraging during the coldest months of the year and (2) free swimming veliger larvae could quickly colonize exploited areas the following growing season. However, reduced ice coverage on Lake Ontario (Assel 2003) allows more ducks to over-winter and exploit macroinvertebrates throughout winter (Petrie and Schummer 2002). In ice-free areas where ducks are able to concentrate and over-winter, more substantial effects on macroinvertebrate populations are possible (Pedroli 1981; Suter 1982a,b,c; Marsh 1986; Hamilton et al. 1994; Sekiya et al. 2000). We predicted that at ice-free areas of Lake Ontario during winter: 1) waterfowl would exploit and decrease local populations of benthic macroinvertebrates throughout winter and 2) spatial distributions and species compositions of flocks of diving ducks would change with a decline in food abundance.

\section{STUDY AREA}

This study was carried out along the southeast shoreline of Prince Edward County, Ontario ( $44^{\circ}$ $00^{\prime} \mathrm{N}, 77^{\circ} 55^{\prime} \mathrm{W}$; Fig. 1), during October to April, 2002-03 and 2003-04. Substrate and vegetation varies across the study area with mud substrate and abundant aquatic macrophytes in the west and rock substrate with little or no vegetation at the east end of Prince Edward Bay. Limestone rock and a gradual slope typify the substrate from Long Point to Point Petre (Barton 1986). Therefore, during winter when shallow bays are covered with ice at the west end of Prince Edward Bay, food is generally limited to benthic macroinvertebrates in areas of rock substrate at the east end of Prince Edward Bay. The study area was divided into five major divisions based on aspect, bathymetry, and primary substrate (West End, North Shore, South Shore, False Ducks, and Lake Shore; Fig 1).

\section{METHODS}

Benthic sampling was used to determine if numbers of macroinvertebrates decreased from fall through spring along the southeast shoreline of Prince Edward County, Lake Ontario during 2002-03 and 2003-04. Much of Prince Edward Bay froze in January and ducks were subsequently observed feeding relatively close to ice banks that formed between Long Point and Point Petre during 2002-03 (Fig. 1). To determine the abundance of macroinvertebrates at the ice-water interface, nektonic and benthic samples were collected throughout winter 2003-04. Waterfowl surveys and 30-min behavioral observations were used to determine spatial distributions and flocking behavior of buffleheads (Bucephala albeola), common goldeneyes (B. clangula), and long-tailed ducks (Clangula hyemalis). These three species represented $>95 \%$ of all waterfowl observed throughout winter on our study area.

\section{Autumn and Spring Benthic Sampling}

To determine food abundance during fall and spring, macroinvertebrates were sampled with drags from a boat (18-21 October and 19-23 April 200203, 19-22 October and 22-28 April 2003-04). 


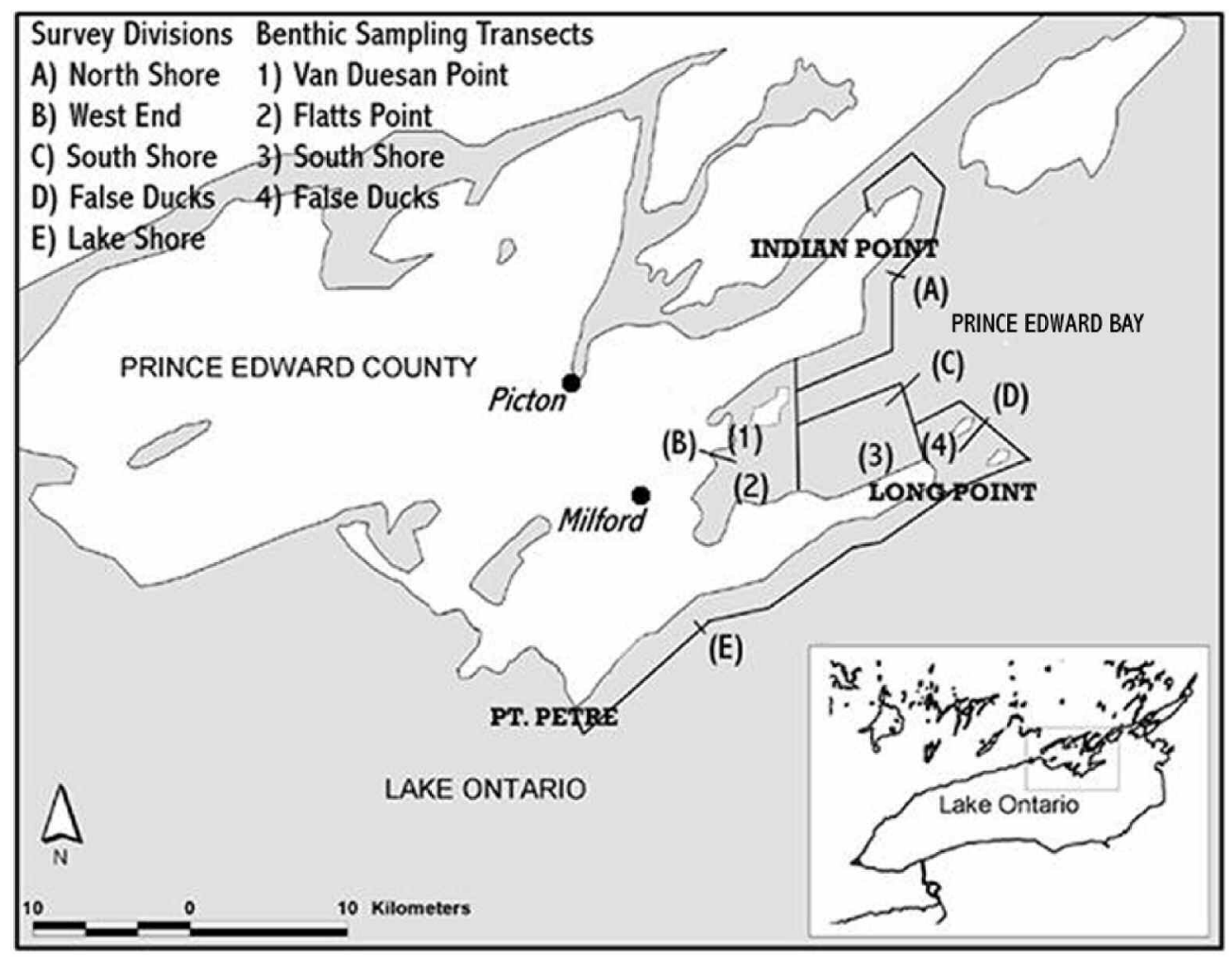

FIG. 1. Map of study area including Prince Edward Bay, shoreline from Long Point through Point Petre and associated islands. Approximate locations of benthic sampling transects are shown as numbers. Major waterfowl survey divisions are labeled with capital letters.

Benthic samples were collected at four geographic locations (Fig. 1) at $<2 \mathrm{~m}, 5 \mathrm{~m}, 10 \mathrm{~m}, 15 \mathrm{~m}, 20 \mathrm{~m}$, and $25 \mathrm{~m}$ depths in 2002-03. Each geographic location consisted of three transects oriented perpendicular to the shoreline approximately $100 \mathrm{~m}$ apart. To ensure that samples were statistically independent, spring samples were collected parallel to and approximately $50 \mathrm{~m}$ away from fall transects. Samples were only collected out to $15 \mathrm{~m}$ at Flatts Point and Van Duesan Point because the western end of Prince Edward Bay is relatively shallow. In 2003-04, samples at 20 and $25 \mathrm{~m}$ could not be collected because of poor weather conditions during sampling periods. Due to equipment problems in 2003-04, samples at $15 \mathrm{~m}$ could not be collected at Flatts Point. Due to rock substrate over the majority of the study area (approximately 90\%), a steel framed benthic sampler (Halltech Inc., Guelph, Ontario) with 250- $u$ m netting was used to collect samples. The benthic sampler (frame opening $=75 \mathrm{~cm}$ wide $\times 30 \mathrm{~cm}$ high) included a 4.54-kg downrigger ball $2 \mathrm{~m}$ ahead of the sled to ensure consistent bot- tom contact. The sled was dragged along the bottom, towed from the surface by a 6-meter boat with a 30-hp engine. To standardize drags, we used markers on the rope to maintain a ratio of 2:1 (rope length:depth), idled the boat engine until the line was tight before starting drags, maintained constant engine speed at three-quarter full throttle during drags and sampled for a 5-s period. We used 5-s drags because longer sampling periods often resulted in large, nearly irretrievable samples because of sample weight. Upon retrieval, samples were transferred from the sled into a $1 \mathrm{~m} \times 1 \mathrm{~m}$ tray with $0.16-\mathrm{cm}$ aluminum window screen for sorting. Large clumps of mussels were transferred to plastic bags. Remaining smaller macroinvertebrates were washed into bags by forming the aluminum screen into a column within a plastic funnel. Following washing and visual inspection, remaining macroinvertebrates were removed from the screen and placed in sample bags. Between drags the benthic sled was thoroughly cleaned and inspected for any remaining macroinvertebrates. Samples were placed 
in a freezer within $3 \mathrm{~h}$ of collection and were later transferred to the University of Western Ontario, London, Ontario in coolers and kept frozen until identified, counted, and measured in the laboratory.

\section{Winter Benthic and Nektonic Sampling}

To determine food abundance during winter near the ice bank/water interface, nektonic (27 Dec 2003-24 Mar 2004) and benthic (29 Jan-24 Mar 2004) samples were collected from locations that could be accessed at Lake Shore, False Ducks, South Shore, and North Shore. We constructed the nektonic sampler by using hose clamps to secure a $0.16-\mathrm{cm}$ fiberglass screen onto the small end of a standard stovepipe expander (large end $=20 \mathrm{~cm}$ ). We used a small hand thrown benthic sled to collect samples during winter. The winter benthic sampler $(25 \times 20 \mathrm{~cm})$ was an aluminum frame $(2.27 \mathrm{~kg})$ with a 5.08-cm diameter PVC pipe sewn into 250$u$ m netting (Halltech Inc., Guelph, Ontario). Hose clamps were used to secure a $0.16-\mathrm{cm}$ fiberglass screen to the PVC pipe.

Samples were collected opportunistically, but we attempted to sample three times per week within each major waterfowl survey division area. Topography of ice banks changed continually, resulting in different areas where water was accessible at different times. We further randomized the sampling by never sampling the exact location on two consecutive sampling days. Both sampling devices were hand thrown perpendicular to shore and retrieved with a nylon rope (marked every $1 \mathrm{~m}$ ) attached to the sampling devices. Nektonic samples were standardized (macroinvertebrates $/ \mathrm{m}$ ) by retrieving the sampling device at approximately one half the total depth of the water column. The benthic sled was hand retrieved at a constant speed (approximately $1 / 2 \mathrm{~m} / \mathrm{sec}$ ) while maintaining contact with the bottom. Benthic samples were standardized (macroinvertebrates $/ \mathrm{m}$ ) by recording the distance that the sled was dragged. Three samples (nektonic and benthic) were collected every $100 \mathrm{~m}$ at each sampling site. To transfer a sample, hose clamps were loosened and the entire sample with the fiberglass screen was placed into a plastic bag. Samples with few macroinvertebrates were counted within $24 \mathrm{~h}$ of collection. Larger samples were frozen, transferred to the University of Western Ontario, London, Ontario in coolers and then placed in freezers until identified, counted, and measured at the laboratory.

\section{Macroinvertebrate Laboratory Procedures}

Macroinvertebrate samples were thawed over night at $3^{\circ} \mathrm{C}-5^{\circ} \mathrm{C}$, washed in a $250-u \mathrm{~m}$ sieve and uniformly mixed in a pan divided into $2.54-\mathrm{cm}$ squares. All macroinvertebrates were identified and counted within randomly selected squares to determine relative abundance using a subsampling approach (King and Richardson 2002, Schummer $2005)$. Using a dissecting microscope $(6 \times$ power) macroinvertebrates from subsamples were identified to taxonomic order (except Gastropoda and Diptera, which were identified to family). Since long-tailed ducks fed on shell-free tissue of dreissenid mussels broken in the surf (Schummer et al. 2008), individual mussels were identified by orange colored demibranch (i.e., mussel feeding apparatus) and surrounding visceral mass.

\section{Waterfowl Surveys}

To minimize effects of human disturbance on estimates of habitat use, surveys were started near the end of hunting season (Owen 1977, Madsen 1995). The end of the survey period was determined by rapid, large increases in waterfowl numbers (i.e., spring migrants) coinciding with warmer temperatures and decreasing ice coverage. Weekly surveys of all waterfowl were conducted by a single observer and recorder 15 December 2002 to 16 March 2003 and 21 December 2003 to 29 February 2004 on a standard route along the southeast shoreline of Prince Edward County, Lake Ontario (approximately $60 \mathrm{~km}$ of shoreline). In 2002-03, Lake Shore was not surveyed, but all five divisions were surveyed in $2003-04$ to better record bird use of the entire study area. Starting locations alternated weekly between Indian Point and Point Petre (Fig. 1). Observers were able to obtain total counts for the North Shore, West End, South Shore, and False Ducks areas. However, road access to the Lake Shore survey area was limited and total numbers of birds were estimated from three locations encompassing $5 \%$ of the total area. We used linear scaling (i.e., we divided the number of birds estimated in $5 \%$ of the study area by 0.05 ) to estimate the population of birds in the entire Lake Shore area. Ducks were fairly evenly distributed along the Lake Shore area (personal observation), and this likely reduced error associated with estimations.

Visual coverage of areas differed due to variation in topography across the study area. Bluffs at West End, South Shore, and False Ducks made it possible to survey birds accurately up to $4 \mathrm{~km}$ from shore. 
Schummer et al.

However, due to low elevations of survey routes along North Shore and Lake Shore, $2 \mathrm{~km}$ was considered the maximum distance birds could be counted accurately. Observations from shore with a spotting scope throughout winter, as well as an aerial survey conducted on 23 February 2004, established that nearly all birds (>95\%) were within 1 $\mathrm{km}$ of shore. Surveys took approximately $4 \mathrm{~h}$ to complete and start times were cycled equally between 1) $800 \mathrm{~h}$, 2) $1000 \mathrm{~h}$ and 3) $1200 \mathrm{~h}$. When visibility was poor, surveys were delayed until the following day. Observations were made with a 10$60 x$ spotting scope and $10 \times 40$ binoculars. Ice coverage $(\%)$ of each survey area was estimated by drawing the extent of ice onto a map comprised of a grid made up of 500-m $\times 500-\mathrm{m}$ cells. Percent ice coverage was determined by dividing the number of cells that were at least $50 \%$ ice by the total number of cells within a study area. Because size of survey areas differed and available habitat changed weekly due to ice coverage, survey data were standardized by calculating the number of birds/square $\mathrm{km}$ of open water for each survey division.

Instantaneous observations were conducted during counts for buffleheads, common goldeneyes, and long-tailed ducks (Altman 1974). Observations included number of birds, primary activity of the flock (i.e., feeding, loafing), distance of flock from shore (recorded with a rangefinder [Bushnell Yardage Pro 1000] and/or known landmarks), and degree of spatial segregation with other species. Distance from shore and bathymetry maps were used to estimate foraging depth. The degree that other species were grouped with observed flocks was scored as: 0) not grouped-average birds $>20 \mathrm{~m}$ apart, 1) loosely grouped-average birds between 2-20 m apart, and 2) tightly grouped - average birds $<2 \mathrm{~m}$ apart. Birds generally surfaced within a few meters of an initial dive. We assumed that a distance of $20 \mathrm{~m}$ was an adequate distance to preclude interaction of diving ducks foraging on the benthos. Waterfowl surveys were not conducted at Lake Shore during 2002-03, but detailed 30-min flock scans were conducted during 2002-03. To include all survey areas in analyses of flocking behavior, data from 30-min flock scans (conducted as part of a larger study on behavior of diving ducks; see Schummer 2005) were included with instantaneous observations from waterfowl surveys to incorporate a wider range of study dates and potential environmental conditions. Half-hour flock scans produced the same type of data as instantaneous observations because flock scans conducted every minute were averaged for the entire $30-\mathrm{min}$. Halfhour flock scans were conducted during daylight hours with $10 \times 40$ binoculars and/or a $10-60 \times$ spotting scope. We distributed observations evenly between morning (sunrise to 1000), midday (1000 to 1400), and evening periods (1400 to sunset). Flocks were arbitrarily selected by swinging the scope across the range of visible flocks and selecting the one closest to the center of field of view when the scope came to rest (Quinlan and Baldassarre 1984, Lovvorn 1989, Poulton et al. 2002). Observations of behavior were conducted every $60 \mathrm{~s}$ for $30 \mathrm{~min}$ (Goudie and Ankney 1986) and included number of ducks, activities of individual ducks (e.g., feeding, loafing), average distance of the flock from shore, and degree of spatial segregation with other species. Data from flock scans conducted every minute were averaged for the entire $30 \mathrm{~min}$ period.

\section{Statistical Analyses}

\section{Autumn and Spring Benthic Sampling}

Water depth can have a strong influence on abundance of benthic macroinvertebrates (Barton 1986, Stewart and Haynes 1994). Because of an uneven sampling scheme at deeper depths, analysis was restricted to $<2,5$, and $10 \mathrm{~m}$. Furthermore, $>90 \%$ of diving ducks were observed feeding in water less than $10 \mathrm{~m}$ deep (Schummer 2005). However, we graphically presented means \pm SE deeper than $10 \mathrm{~m}$ for descriptive purposes. We assumed that the same amount of bottom area was covered with each sample. However, we were unsure of the distance sampled during drags because we were unable to estimate boat speed during sampling periods that only lasted $5 \mathrm{~s}$. Therefore, we used number of macroinvertebrates/sample in statistical analyses. Macroinvertebrate data were tested for normality and $\log$-transformed $(\ln )$ where appropriate, to achieve approximate normality of residuals and homogeneity of variance.

We used analysis of variance (ANOVA, PROC GLM, SAS Institute Inc. 1990) to determine if numbers of macroinvertebrates in each taxon differed by year, season, location, and depth. Year, season, location, depth, and all interactions were used as categorical variables to examine variation in numbers of Gastropoda (Valvatidae, Hydrobiidae, Pleuroceridae, Lymnaeidae, Physidae, and Planorbidae), dreissenid mussels (quagga and zebra mussels combined), Trichoptera, Chironomidae, Amphipoda, and Isopoda per sample. Dreissenid 
mussels were combined because zebra mussels accounted for a low percentage $(<2 \%)$ of total mussels and quaggas dominated all samples. Sphaeriidae, Oligochaeta, Bythniidae, and Ancylidae represented a small portion $(<1 \%$ combined) of macroinvertebrates collected, were not consumed by diving ducks (Schummer et al. 2008), and subsequently, were not included in the analyses. Statistical models and differences among means were considered statistically significant at $\mathrm{P} \leq 0.05$, but worthy of biological interpretation and discussion at $\mathrm{P} \leq 0.10$. Only significant interaction terms were included in tables. P-values for all main effects included in interaction terms were included whether significant or not.

\section{Winter Benthic and Nektonic Sampling}

For each macroinvertebrate taxon, we used general linear models (PROC GLM, SAS Institute Inc. 1990) to determine if abundance differed by location, date and location $\mathrm{x}$ date. Data were tested for normality and $\log$ transformed (ln) where appropriate. Depth was not included as an independent variable in the models because depth was relatively constant (range approximately $0.5-2.0 \mathrm{~m}$ ) when sampling nearshore areas. Sampling location was used as a categorical variable and sampling date as a continuous variable to examine variation in numbers of shell-free dreissenid mussel tissue, dreissenid mussels (quagga and zebra mussels combined), Amphipoda, Chironomidae, Trichoptera, Valvatidae, Hydrobiidae, Pleuroceridae, Lymnaedae, Physidae, Planorbidae, and Isopoda per meter sampled.

\section{Waterfowl Surveys}

General linear models (PROC GLM, SAS Institute Inc. 1990) were used to determine density and habitat use patterns of ducks. Sampling location was used as a categorical variable and sampling date as a continuous variable to examine variation in number of ducks per square $\mathrm{km}$ of open water throughout winter. When location was found to be significant we used Tukey's Honest Significant Difference (HSD) to determine differences in mean duck use between locations. When date was found to be significant by location, slopes $(\beta)$ from general linear models were used to determine if numbers of birds were increasing or decreasing within each survey area (PROC REG, SAS Institute Inc. 1990).

The distance from shore that flocks foraged and regularity of mixed species flocks were used as fine-scale measures of spatial distributions of birds. Because observers could not accurately determine the distance flocks were from shore beyond $500 \mathrm{~m}$, data were categorized as $<50,51-250,251-500$ and $>500 \mathrm{~m}$. To better identify interactions between numbers of macroinvertebrates and diving duck use, only flocks of birds that were primarily foraging were used to analyze distributions of birds within distance categories. Within survey location we determined if species were distributed equally across distance categories using a chi-square test (PROC FREQ, SAS Institute Inc. 1990). Multivariate analysis of variance (MANOVA) was used to determine if overall flock grouping scores, ranging from 0-2, differed among species, location and species $\times$ location (PROC GLM, SAS Institute Inc. 1990). Wilks' $\lambda$ was used as the test statistic. Following a significant MANOVA, univariate analyses were used to determine if flock grouping scores differed between locations for each species (PROC GLM, SAS Institute Inc. 1990). We used Tukey's Honest Significant Difference (HSD) to determine differences in mean flock grouping scores between locations for each species.

General linear models (PROC GLM, SAS Institute Inc. 1990) were used to determine if the number of nearshore macroinvertebrates influenced densities of buffleheads, common goldeneyes, and/or long-tailed ducks within survey divisions. Data were tested for normality and log transformed (ln) where appropriate. For each major survey division, mean number of macroinvertebrates were estimated from winter benthic and nektonic samples collected within seven days preceding waterfowl surveys and used as predictors of weekly densities of buffleheads, common goldeneyes, and longtailed ducks (PROC GLM, SAS Institute Inc. 1990). We also used macroinvertebrate densities as predictors of mean weekly duck use within survey divisions (PROC GLM, SAS Institute Inc. 1990).

\section{RESULTS}

\section{Autumn and Spring Benthic Sampling}

Numbers of macroinvertebrates did not change from fall through spring in a consistent manner throughout Prince Edward Bay (Appendix 1). Significant interactions of season with depth and location were more common than seasonal effects alone. Overall, macroinvertebrate numbers were most influenced by depth and sampling location (Appendix 1, Fig. 2). Dreissenid mussels did not 


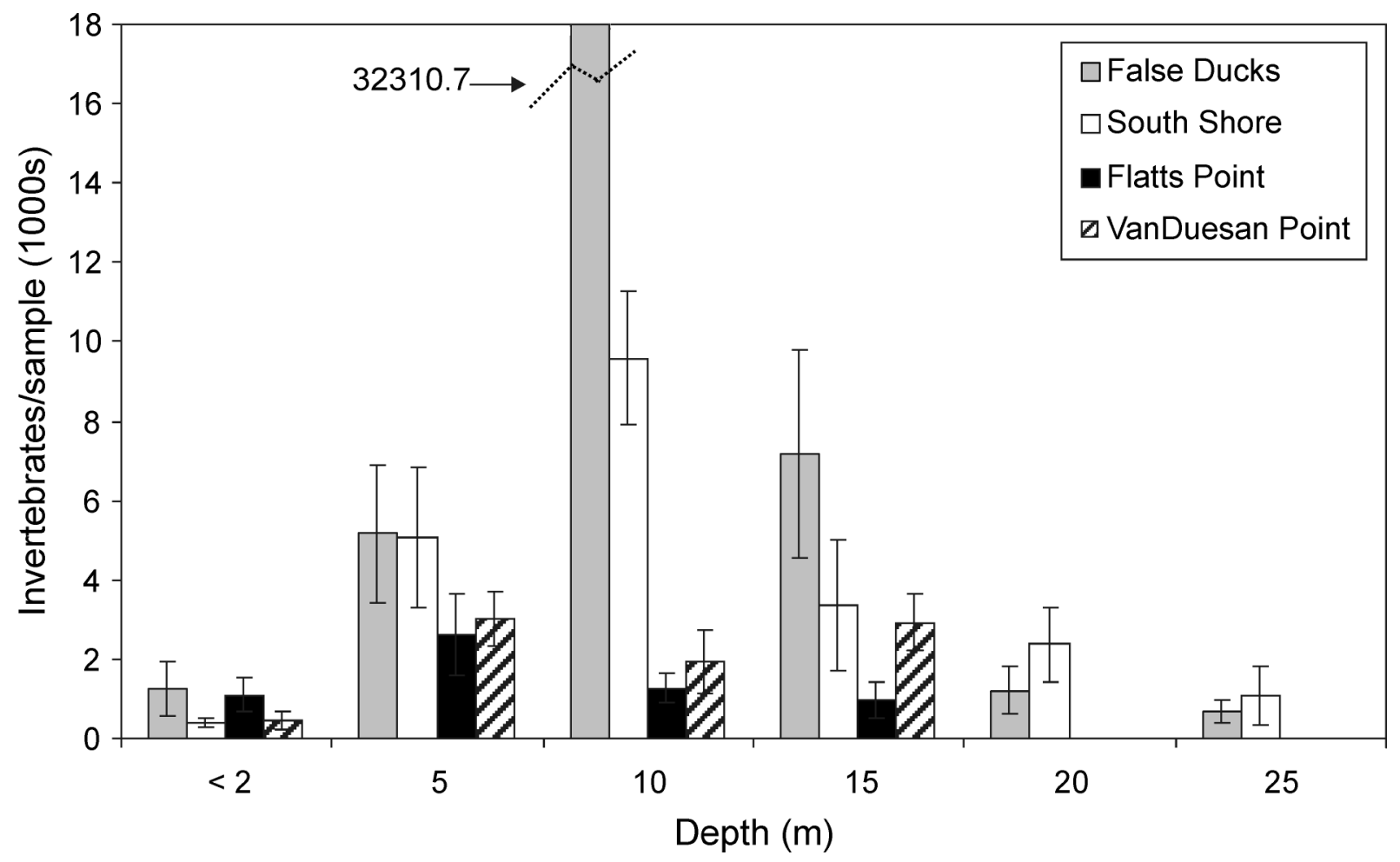

FIG. 2. Mean total number of invertebrates $( \pm S E)$ per benthic sample by depth and location at Prince Edward Bay, Lake Ontario, 2002-03 and 2003-04. Note: samples were not collected at Flatts or Van Duesan Points at 20-m or 25-m depth intervals.

decline from fall through spring, comprised the majority of the macroinvertebrate community at all sampling locations (range $=81.0 \%-88.3 \%$ ), and greatly influenced trends in total macroinvertebrates in Prince Edward Bay. The remainder of the community consisted primarily of Gastropoda $($ range $=2.43 \%-4.76 \%)$, Chironomidae $($ range $=$ $2.15 \%-7.36 \%$ ) and Amphipoda (range = $3.46 \%-5.82 \%$ ). Lower numbers of Gastropoda per sample were documented during spring than fall at nearly all sampling locations (Appendix 1). Seasonal declines in numbers of Amphipoda and dreissenid mussels per sample were greater at False Ducks than other sampling locations (Appendix 1, Fig. 3). Large decreases in dreissenid mussels occurred from fall through spring at shallow areas of False Ducks, but this relationship was not evident at deeper sampling locations or for most sampling locations at the western end of the bay (Appendix 1, Fig. 3; SEASON $\times$ LOCATION $\times$ DEPTH effect). Numbers of Chironomidae and Amphipoda differed by season and location. Numbers of Chironomidae were greater in spring than fall at nearly all locations sampled (Appendix 1). Similar to mussels, numbers of Amphipoda decreased at False Ducks but not at other sampling locations (SEASON $\times$ LOCATION effect). Trichoptera and Isopoda comprised a small percentage of the benthic macroinvertebrate community and followed a similar pattern of limited seasonal influence and strong depth and location effects.

\section{Winter Benthic and Nektonic Sampling}

Variation in ice cover limited accessibility to some of the sampling locations in winter. Lake Shore was regularly accessible (nektonic $n=111$ samples collected, benthic $n=75$ ) but nearshore ice (usually $<10 \mathrm{~m}$ from shore) at False Ducks (nektonic $n=18$, benthic $n=15$ ), South Shore (nektonic $n=27$, benthic $n=12$ ), and North Shore (nektonic $n=24$, benthic $n=12$ ) resulted in reduced sample sizes (Table 1). In contrast to fall and spring benthic samples, winter samples were comprised mostly of Amphipoda (11.8\%) and Chironomidae (65.1\%; Table 1). Samples also included dreissenid mussels $(11.1 \%)$, dreissenid tissue $(9.1 \%)$, and fish eggs (1.5\%). Macroinvertebrates collected in benthic and 

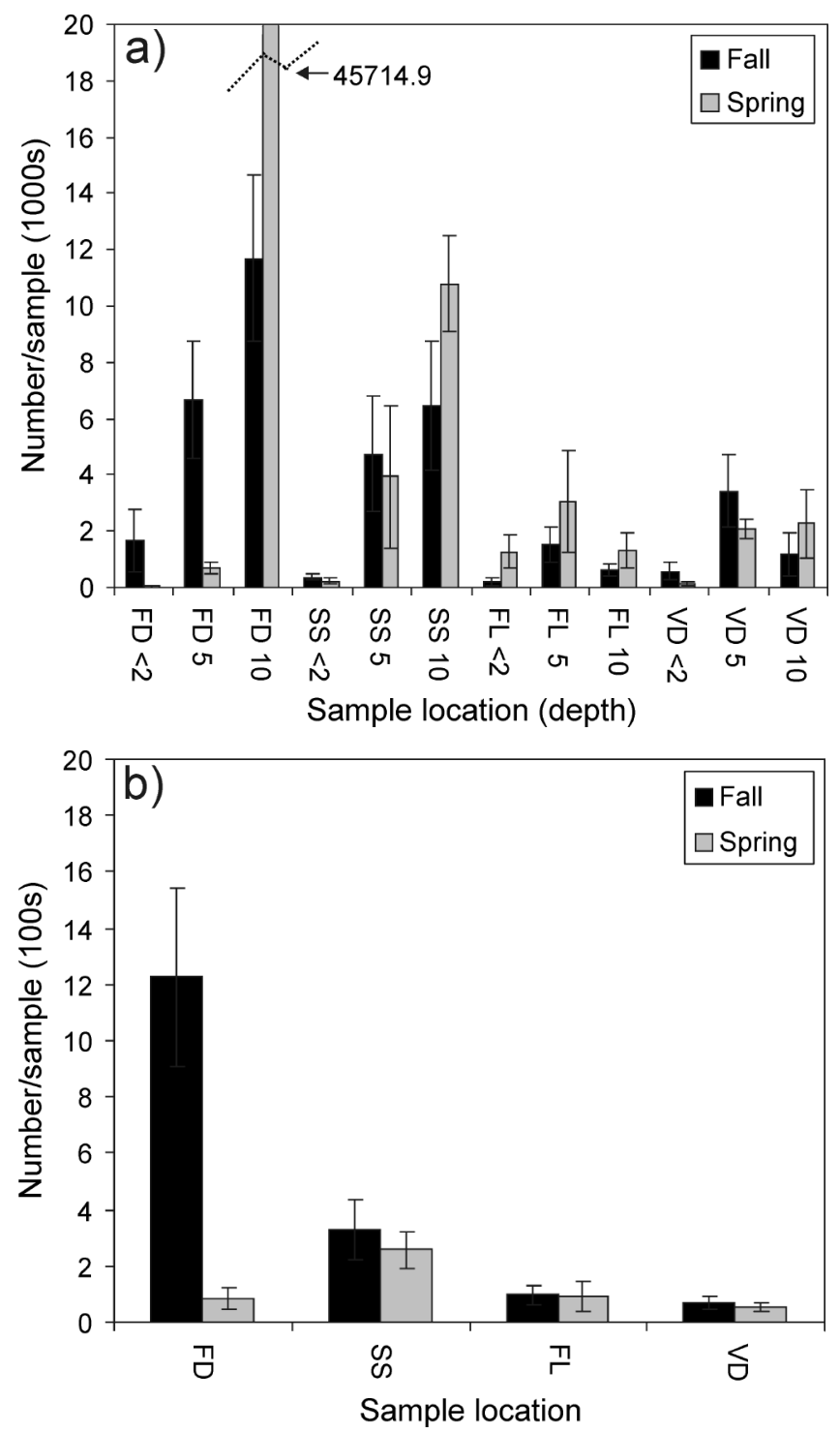

FIG. 3. Mean numbers of A) dreissenid mussels and B) Amphipoda ( \pm SE) per benthic sample at different locations and/or depths by season at Prince Edward Bay, Lake Ontario 2002-03 and 2003-04. Abbreviations: $F D=$ False Ducks, $S S=$ South Shore, FL = Flatts Point, VD = Van Duesan Point.

nektonic samples did not decrease in abundance throughout winter and were most abundant at False Ducks and Lake Shore (Table 1).

\section{Waterfowl Use}

Long-tailed ducks were most abundant throughout winter followed by common goldeneyes and buffleheads (Table 2). Use of survey areas differed by species and changed over time during both winters (Table 2). Lake Shore and False Ducks received the highest and most consistent use of all survey areas even prior to periods of increased ice coverage during mid-winter. Diving ducks used the west end of the Prince Edward Bay until ice formation, when birds relocated east towards False Ducks and Lake Shore (Table 2). Only long-tailed ducks were regularly observed at South Shore. Densities of buffleheads $\left(\beta=0.27, \mathrm{r}^{2}=0.10, \mathrm{~F}_{1,42}=4.34, \mathrm{P}\right.$ $=0.043)$, common goldeneyes $\left(\beta=0.13, \mathrm{r}^{2}=0.09\right.$, $\left.\mathrm{F}_{1,42}=4.30, \mathrm{p}=0.0444\right)$, and long-tailed ducks $\left(\beta=0.20, \mathrm{r}^{2}=0.15, \mathrm{~F}_{1,42}=5.43, \mathrm{P}=0.022\right)$ were positively associated with areas of higher nearshore food abundance as calculated from winter benthic and nektonic samples. Densities of all species combined were also positively associated with food abundance in nearshore areas $\left(\beta=7.17, \mathrm{r}^{2}=0.91\right.$, $\mathrm{F}_{1,3}=20.17, \mathrm{P}=0.046$; Fig. 4).

The distance from shore that flocks foraged $(n=$ 1123 flocks) differed by species within survey locations (False Ducks, $x^{2}=174.37$, df $=6, \mathrm{P}<0.0001$; Lake Shore, $x^{2}=136.12$, df $=6, \mathrm{P}<0.0001$; North Shore, $x^{2}=218.32$, df $=6, \mathrm{P}<0.0001$; South Shore [LTDU and COGO only], $x^{2}=198.84$, df $=3$, $\mathrm{P}<0.0001$; West End, $x^{2}=107.17$, df $=6, \mathrm{p}<$ 0.0001; Fig. 5). Flock mixing scores differed by species and location (MANOVA; df $=2057$, Wilks' $\lambda=0.95, \mathrm{P}<0.01)$. Buffleheads had the highest flock mixing scores and frequency of flock mixing followed by common goldeneyes and long-tailed ducks (Table 3). Mixed species flocks were most common at Lake Shore and False Ducks. Mixed flocks of buffleheads and common goldeneyes where also common at North Shore and West End where long-tailed ducks were relatively absent. No mixing of species was observed at South Shore.

\section{DISCUSSION}

We predicted that the large number of diving ducks wintering on northeastern Lake Ontario would cause a decrease in food abundance throughout winter. Although differences in macroinvertebrate densities by location and depth likely influenced habitat use by diving ducks, we found little evidence to suggest that foraging by diving ducks caused decreases in macroinvertebrate abundance during winter. Furthermore, patterns of habitat use and flocking behavior differed by species, but did not change throughout winter in a manner consistent with decreasing availability of food. Had food become limiting, we would have expected in- 
TABLE 1. Mean ( $\pm S D)$ number of macroinvertebrates per meter sampled (median, maximum) at four locations along the southeast shoreline of Prince Edward County, Lake Ontario, Canada, January-March 2004.

\begin{tabular}{|c|c|c|c|c|c|c|c|}
\hline & \multicolumn{4}{|c|}{ Location } & \multirow{2}{*}{\multicolumn{3}{|c|}{ Effects $(\mathrm{F}, \mathrm{P})^{*}$}} \\
\hline & Lake Shore & False Duck & North Shore & South Shore & & & \\
\hline & \multicolumn{4}{|c|}{ Benthic } & & & \\
\hline Taxon & $\mathrm{n}=75$ & $\mathrm{n}=15$ & $\mathrm{n}=12$ & $\mathrm{n}=12$ & $\mathrm{~L}_{\mathrm{df} 3,110}$ & $\mathrm{D}_{\mathrm{df} 3,110}$ & $\mathrm{~L} \times \mathrm{D}_{\mathrm{df}} 9,110$ \\
\hline $\begin{array}{l}\text { Dreissenid } \\
\text { mussel whole }\end{array}$ & $\begin{array}{c}3.39 \pm 17.16 \\
(0,116.00)\end{array}$ & $\begin{array}{c}2.19 \pm 4.97 \\
(0.10,15.58)\end{array}$ & $\begin{array}{l}0.27 \pm 0.40 \\
(0.08,1.19)\end{array}$ & $\begin{array}{c}1.45 \pm 4.72 \\
(0.04,16.42)\end{array}$ & ns & ns & ns \\
\hline $\begin{array}{l}\text { Dreissenid } \\
\text { mussel tissue }\end{array}$ & $\begin{array}{c}3.20 \pm 7.11 \\
(0.36,33.60)\end{array}$ & $\begin{array}{c}1.06 \pm 3.00 \\
(0,11.20)\end{array}$ & $\begin{array}{l}0.99 \pm 2.66 \\
(0.09,9.33)\end{array}$ & $\begin{array}{l}0.02 \pm 0.06 \\
(0,0.21)\end{array}$ & $\begin{array}{l}3.19 \\
0.03\end{array}$ & ns & $\mathrm{ns}$ \\
\hline Chironomidae & $\begin{array}{l}17.04 \pm 38.86 \\
(1.82,198.55)\end{array}$ & $\begin{array}{l}36.92 \pm 86.36 \\
(1.00,278.13)\end{array}$ & $\begin{array}{c}6.81 \pm 9.41 \\
(1.96,30.81)\end{array}$ & $\begin{array}{l}0.31 \pm 0.76 \\
(0,2.64)\end{array}$ & $\begin{array}{l}2.98 \\
0.03\end{array}$ & ns & ns \\
\hline Amphipoda & $\begin{array}{c}3.37 \pm 8.21 \\
(0.57,48.00)\end{array}$ & $\begin{array}{l}5.91 \pm 19.04 \\
(1.04,74.67)\end{array}$ & $\begin{array}{l}0.43 \pm 0.80 \\
(0.13,2.81)\end{array}$ & $\begin{array}{c}0.09 \pm 0.09 \\
(0,0.10)\end{array}$ & $\begin{array}{l}3.83 \\
0.01\end{array}$ & $\mathrm{~ns}$ & ns \\
\hline \multirow[t]{3}{*}{$\begin{array}{l}\text { Total } \\
\text { invertebrates }\end{array}$} & $\begin{array}{l}28.12 \pm 54.83 \\
(3.00,264.73)\end{array}$ & $\begin{array}{c}47.17 \pm 107.01 \\
(3.20,377.07)\end{array}$ & $\begin{array}{l}8.45 \pm 12.22 \\
(2.21,36.25)\end{array}$ & $\begin{array}{c}1.90 \pm 4.93 \\
(0.22,17.25)\end{array}$ & $\begin{array}{l}3.26 \\
0.02\end{array}$ & ns & ns \\
\hline & \multicolumn{4}{|c|}{ Location } & \multirow{2}{*}{\multicolumn{3}{|c|}{ Effects (F, P-value)* }} \\
\hline & Lake Shore & False Duck & North Shore & South Shore & & & \\
\hline & \multicolumn{4}{|c|}{ Nektonic } & & & \\
\hline Taxon & $\mathrm{n}=111$ & $\mathrm{n}=18$ & $\mathrm{n}=24$ & $\mathrm{n}=27$ & $\mathrm{~L}_{\mathrm{df} 3,176}$ & $\mathrm{D}_{\mathrm{df} 3,176}$ & $\mathrm{~L} \times \mathrm{D}_{\text {df } 9,176}$ \\
\hline $\begin{array}{l}\text { Dreissenid } \\
\text { mussel whole }\end{array}$ & $0 \pm 0$ & $0 \pm 0$ & $0 \pm 0$ & $0 \pm 0$ & & $\mathrm{n} / \mathrm{a}$ & \\
\hline $\begin{array}{l}\text { Dreissenid } \\
\text { mussel tissue }\end{array}$ & $\begin{array}{l}0.21 \pm 0.11 \\
(0,12.42)\end{array}$ & $\begin{array}{l}0.13 \pm 0.11 \\
(0,2.00)\end{array}$ & $\begin{array}{c}0.01 \pm 0.01 \\
(0,0.17)\end{array}$ & $\begin{array}{l}0.01 \pm 0.01 \\
(0,0.10)\end{array}$ & ns & ns & ns \\
\hline Chironomidae & $\begin{array}{l}0.61 \pm 0.13 \\
(0.08,9.06)\end{array}$ & $\begin{array}{c}1.54 \pm 1.03 \\
(0.06,18.57)\end{array}$ & $\begin{array}{l}0.04 \pm 0.02 \\
(0,0.25)\end{array}$ & $\begin{array}{l}0.01 \pm 0.01 \\
(0,0.06)\end{array}$ & $\begin{array}{l}5.70 \\
<0.01\end{array}$ & ns & ns \\
\hline Amphipoda & $\begin{array}{c}0.33 \pm 0.20 \\
(0,22.67)\end{array}$ & $\begin{array}{c}0.39 \pm 0.32 \\
(0,5.86)\end{array}$ & $0 \pm 0$ & $0 \pm 0$ & $\begin{array}{l}2.29 \\
0.08\end{array}$ & ns & ns \\
\hline $\begin{array}{l}\text { Total } \\
\text { invertebrates }\end{array}$ & $\begin{array}{c}1.21 \pm 0.40 \\
(0.25,41.74)\end{array}$ & $\begin{array}{c}2.09 \pm 1.49 \\
(0.11,27.00)\end{array}$ & $\begin{array}{c}0.05 \pm 0.02 \\
(0,0.42)\end{array}$ & $\begin{array}{c}0.01 \pm 0.01 \\
(0,0.18)\end{array}$ & $\begin{array}{l}6.59 \\
<0.01\end{array}$ & ns & ns \\
\hline
\end{tabular}

$* \mathrm{~L}=$ Location, $\mathrm{D}=$ Date

creases in spatial segregation as species began to specialize within habitats where food items existed that they were best adapted to exploit. Furthermore, aggression was not observed (Schummer 2005), again suggesting that food was readily available (Lima 1986).

Declines in some taxa of benthic macroinvertebrates might not have resulted from predation by diving ducks. Excluding Amphipoda and dreissenid mussels, declines in benthic macroinvertebrates were observed both in areas covered by ice throughout winter and areas that were relatively ice-free, exposed for months to foraging by diving ducks. Non-predatory decreases in invertebrates have been recorded within aquatic systems during winter and are often attributed to extent of ice coverage, length of winter, anoxia, senescence of macrophyte vegetation, and physiological cycles (Barton and Griffiths 1984, Thorp and Covich 1991). However, reductions in Amphipoda and 
TABLE 2. Mean ( \pm SD) number of diving ducks per square $\mathrm{km}$ of open water and trend in abundance ( $\beta, P$-value) along the southeast shoreline of Prince Edward County, Lake Ontario, Canada, December-March, 2002-2004.

\begin{tabular}{|c|c|c|c|c|c|c|c|}
\hline \multirow[b]{2}{*}{ Species** } & \multirow[b]{2}{*}{ Year $_{\mathrm{df}}$} & \multicolumn{6}{|c|}{ Location* } \\
\hline & & West End & North Shore & South Shore & False Ducks & Lake Shore & Total Area \\
\hline \multirow[t]{2}{*}{$\overline{\mathrm{BUFF}}$} & $2002-03_{13}$ & $\begin{array}{l}0.15 \pm 0.10^{\mathrm{ab}} \\
(-0.01,0.09)\end{array}$ & $\begin{array}{l}2.62 \pm 1.63^{b} \\
(0.02,0.05)\end{array}$ & $\begin{array}{c}0.00 \pm 0.00^{\mathrm{a}} \\
(\text { - })\end{array}$ & $\begin{array}{c}1.16 \pm 0.73^{\mathrm{ab}} \\
(0.01, \mathrm{~ns})\end{array}$ & Not surveyed & $0.98 \pm 0.45$ \\
\hline & $2003-04_{10}$ & $\begin{array}{c}0.04 \pm 0.03^{\mathrm{a}} \\
(-0.01, \mathrm{~ns})\end{array}$ & $\begin{array}{l}0.37 \pm 0.18^{\mathrm{a}} \\
(0.01, \mathrm{~ns})\end{array}$ & $\begin{array}{c}0.00 \pm 0.00^{\mathrm{a}} \\
(-)\end{array}$ & $\begin{array}{c}3.87 \pm 1.45^{\mathrm{b}} \\
(0.02, \mathrm{~ns})\end{array}$ & $\begin{array}{c}40.02 \pm 12.72^{\mathrm{c}} \\
(-0.01, \mathrm{~ns})\end{array}$ & $8.86 \pm 3.26$ \\
\hline \multirow[t]{2}{*}{ COGO } & $2002-03_{13}$ & $\begin{array}{l}10.21 \pm 4.13^{\mathrm{a}} \\
(-0.03,0.02)\end{array}$ & $\begin{array}{c}32.36 \pm 19.94^{a} \\
(0.03,0.05)\end{array}$ & $\begin{array}{c}0.01 \pm 0.01^{\mathrm{b}} \\
(-0.01, \mathrm{~ns})\end{array}$ & $\begin{array}{l}67.94 \pm 47.91^{\mathrm{a}} \\
\quad(0.03, \mathrm{~ns})\end{array}$ & Not surveyed & $27.63 \pm 13.13$ \\
\hline & $2003-04_{10}$ & $\begin{array}{l}5.97 \pm 3.17 \mathrm{ab} \\
(-0.04,0.01)\end{array}$ & $\begin{array}{l}19.97 \pm 15.05^{\mathrm{b}} \\
(0.01, \mathrm{~ns})\end{array}$ & $\begin{array}{l}0.02 \pm 0.01^{\mathrm{a}} \\
(-0.01, \mathrm{~ns})\end{array}$ & $\begin{array}{c}16.25 \pm 5.14^{\mathrm{b}} \\
(0.03,0.09)\end{array}$ & $\begin{array}{c}86.38 \pm 22.15^{\mathrm{c}} \\
(0.04,0.02)\end{array}$ & $25.72 \pm 6.77$ \\
\hline \multirow[t]{2}{*}{ LTDU } & $2002-03_{13}$ & $\begin{array}{c}8.84 \pm 8.25^{\mathrm{a}} \\
(-0.01, \mathrm{~ns})\end{array}$ & $\begin{array}{c}66.73 \pm 66.66^{\mathrm{a}} \\
(0.03,0.09)\end{array}$ & $\begin{array}{c}33.55 \pm 14.30^{\mathrm{ab}} \\
(-0.05,<0.01)\end{array}$ & $\begin{array}{c}371.73 \pm 184.0^{\mathrm{b}} \\
(0.03, \mathrm{~ns})\end{array}$ & Not surveyed & $120.21 \pm 51.68$ \\
\hline & $2003-04_{10}$ & $\begin{array}{c}0.17 \pm 0.12^{\mathrm{a}} \\
(0.01, \mathrm{~ns})\end{array}$ & $\begin{array}{c}0.89 \pm 0.73^{\mathrm{a}} \\
(0.02, \mathrm{~ns})\end{array}$ & $\begin{array}{c}250.75 \pm 205.7^{\mathrm{b}} \\
(0.01, \mathrm{~ns})\end{array}$ & $\begin{array}{c}338.54 \pm 154.4^{\mathrm{b}} \\
(0.05,0.04)\end{array}$ & $\begin{array}{c}148.26 \pm 29.60^{\mathrm{b}} \\
(-0.03, \mathrm{~ns})\end{array}$ & $147.72 \pm 53.09$ \\
\hline
\end{tabular}

Total $\quad 2002-03_{13} \quad 20.08 \pm 11.52^{\mathrm{a}} 104.66 \pm 81.86^{\mathrm{ab}} 33.74 \pm 14.32^{\mathrm{a}} 442.05 \pm 225.7^{\mathrm{b}} \quad$ Not surveyed $150.12 \pm 62.94$

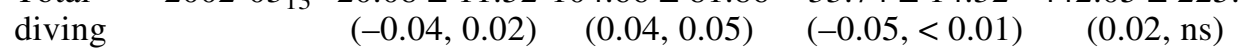

ducks

$2003-04_{10} \quad 13.70 \pm 6.87^{\mathrm{a}} 21.62 \pm 14.95^{\mathrm{ab}} 250.8 \pm 205.7^{\mathrm{bc}} 360.23 \pm 158.5^{\mathrm{cd}} 292.04 \pm 61.15^{\mathrm{d}} 187.69 \pm 55.01$

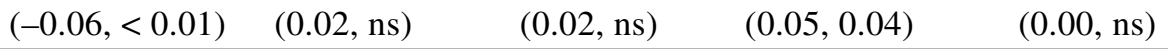

* Locations followed by the same letter are not statistically different (Tukey HSD, P $<0.10$ )

$* * \mathrm{BUFF}=$ bufflehead, $\mathrm{COGO}=$ common goldeneye and LTDU $=$ long-tailed duck

dreissenid mussels observed at False Ducks could be due to foraging by diving ducks. Buffleheads, common goldeneyes, and long-tailed ducks regularly feed on Amphipoda and dreissenid mussels (Hamilton and Ankney 1994, Custer and Custer 1996, Ross et al. 2005, Schummer et al. 2008). Shorelines of False Ducks were exposed to high levels of ice scouring, which could explain decreases in mussels in areas $<2 \mathrm{~m}$. However, decreases in numbers of mussels were also evident at $5 \mathrm{~m}$, and it is unlikely that ice scouring caused these seasonal changes. Previous research indicates that diving ducks can cause decreases in densities of dreissenid mussels, but that these effects were short-term because of recolonization (Hamilton et al. 1994). Similarly, we found large numbers of Amphipoda and dreissenid mussels the following fall at False Ducks where birds had presumably nearly eliminated them the winter before, supporting that foraging effects were short-term.

Abundant nearshore macroinvertebrates that ap- pear to have accumulated due to wave action, ice scouring, and lake currents likely mitigated effects of declines in dreissenid mussels and Amphipoda that occurred in more stable benthic food patches, such as at False Ducks. No decreases in dietary intake of Amphipoda or dreissenid mussels were seen throughout winter for buffleheads, common goldeneyes, or long-tailed ducks (Schummer et al. 2008). Rather, the False Ducks area continued to be utilized by foraging waterfowl throughout winter and nearly all long-tailed ducks collected in this area in February and March had eaten dreissenid mussels (Schummer et al. 2008). Overall, these findings indicated that lower threshold levels of food availability had not been reached throughout the study area.

Our data supported a hypothesis that abiotic factors such as wave action, ice scour, upwellings, local geology, and nutrient availability can affect numbers of nearshore macroinvertebrates (Krecker and Lancaster 1933, Barton and Hynes 1978, Bar- 


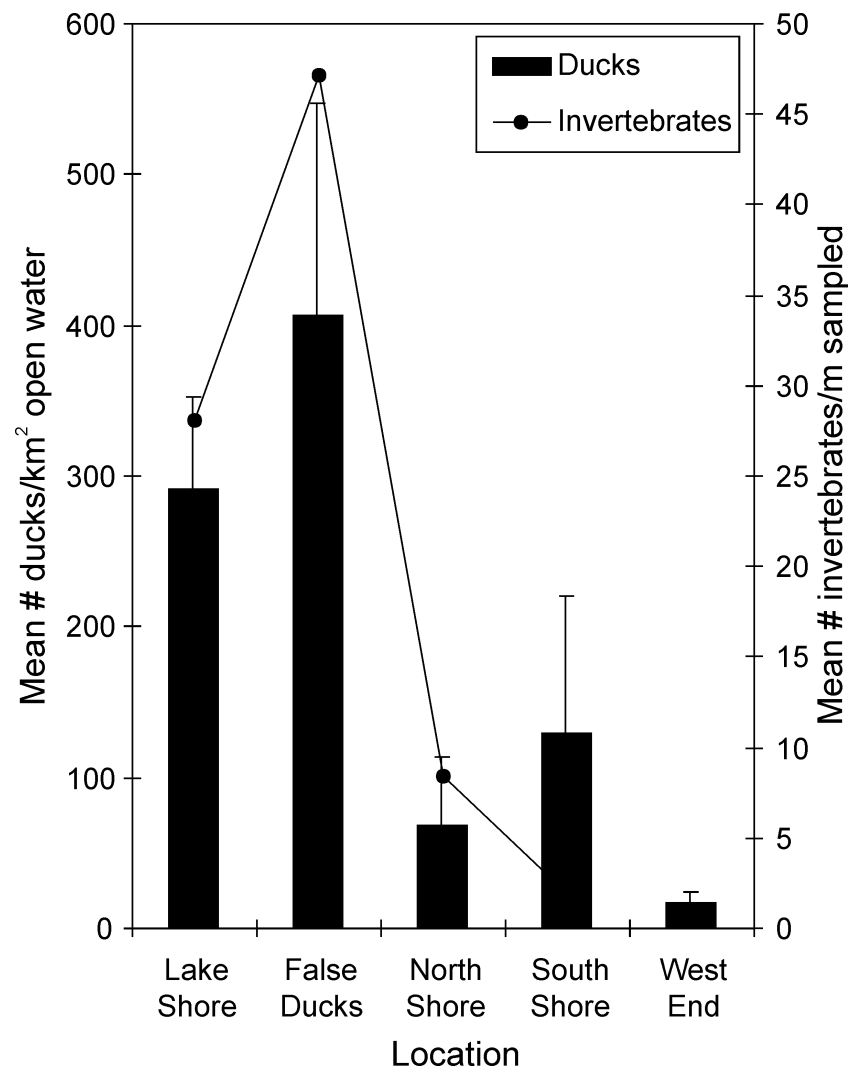

FIG. 4. Comparison between densities of ducks and invertebrate densities along the southeast shoreline of Prince Edward County, Lake Ontario, January to March 2003-04.

ton and Griffiths 1984, Barton 1986, Wisenden and Bailey 1995). Fall and spring sampling indicated that macroinvertebrates were more abundant farther from shore. However, in areas susceptible to abiotic factors such as wave action and ice scouring during winter (i.e., Lake Shore, False Ducks), nearshore macroinvertebrates were distributed in a patchy manner but highly abundant. A mean of approximately 100 macroinvertebrates/m² (mostly Amphipoda and Chironomidae) were available in nearshore areas and densities did not decline throughout winter. However, this resource was highly variable on temporal and spatial scales. Our winter density estimates should be considered conservative because we were unable to sample during high wave conditions, when we observed macroinvertebrates being concentrated into nearshore areas. Consistently high densities of macroinvertebrates throughout winter were unexpected because the flat limestone bedrock that predominated the study area does not provide ideal substrate for burrowing Amphipoda and Chironomidae (Nalepa and Robertson 1981, Thorp and Covich 1991, Gonzalez and Downing 1999). However, increased surface area provided by shells of live and dead dreissenid mussels allows for colonization of normally unsuitable rock substrate by macroinvertebrates (Dermott et al. 1993, Stewart and Haynes 1994, Wisenden and Bailey 1995, Gonzales and Downing 1999, Kuhns and Berg 1999). These areas may not be stable habitats throughout the year, possibly resulting in colonization during summer and removal by scouring during winter storm events (Hamilton et al. 1994) that makes them available to ducks in nearshore areas.

Previous studies indicate that diving ducks generally select habitats with increased food abundance (Nilsson 1972, Stott and Olson 1973, Perhsson 1976, Guillemette et al. 1993). Although food appeared to be abundant in northeastern Lake Ontario in winter, its spatial/temporal availability varied substantially in nearshore areas where many birds fed. This variation, coupled with consistently changing ice conditions, likely resulted in a relatively unpredictable food resource for some diving ducks. Food already distributed in patches, consistently moving during storm events, was likely made more unpredictable by short periods of thin lake ice when openings in the ice may or may not have been positioned over abundant food resources. Therefore, while food was highly abundant and did not decrease substantially throughout winter, the unpredictability of environmental conditions could temporally limit food availability and birds should decrease search time by remaining near locations where food was available in the recent past.

Selection of foraging patches includes trade-offs between various factors including food availability, energy density of available foods, handling time of prey, and costs associated with diving to deeper depths (Woakes and Butler 1983, Krebs and Davies 1991, Ydenburg and Guillemette 1991). Foraging at shallow depths probably requires less energy expenditure, but may not be profitable if food and/or nutrient availability is below threshold levels. An inverse relationship between numbers of benthic macroinvertebrates and depth is the pattern normally found in many aquatic systems (Golikov and Scarlato 1973, Jansson and Kautsky 1977, Barton and Hynes 1978, Barton 1986, Kilgour et al. 2000). However, benthic macroinvertebrates on the Great Lakes generally follow a unimodal distribution with highest abundance at $10-15 \mathrm{~m}$, lower abundance in 


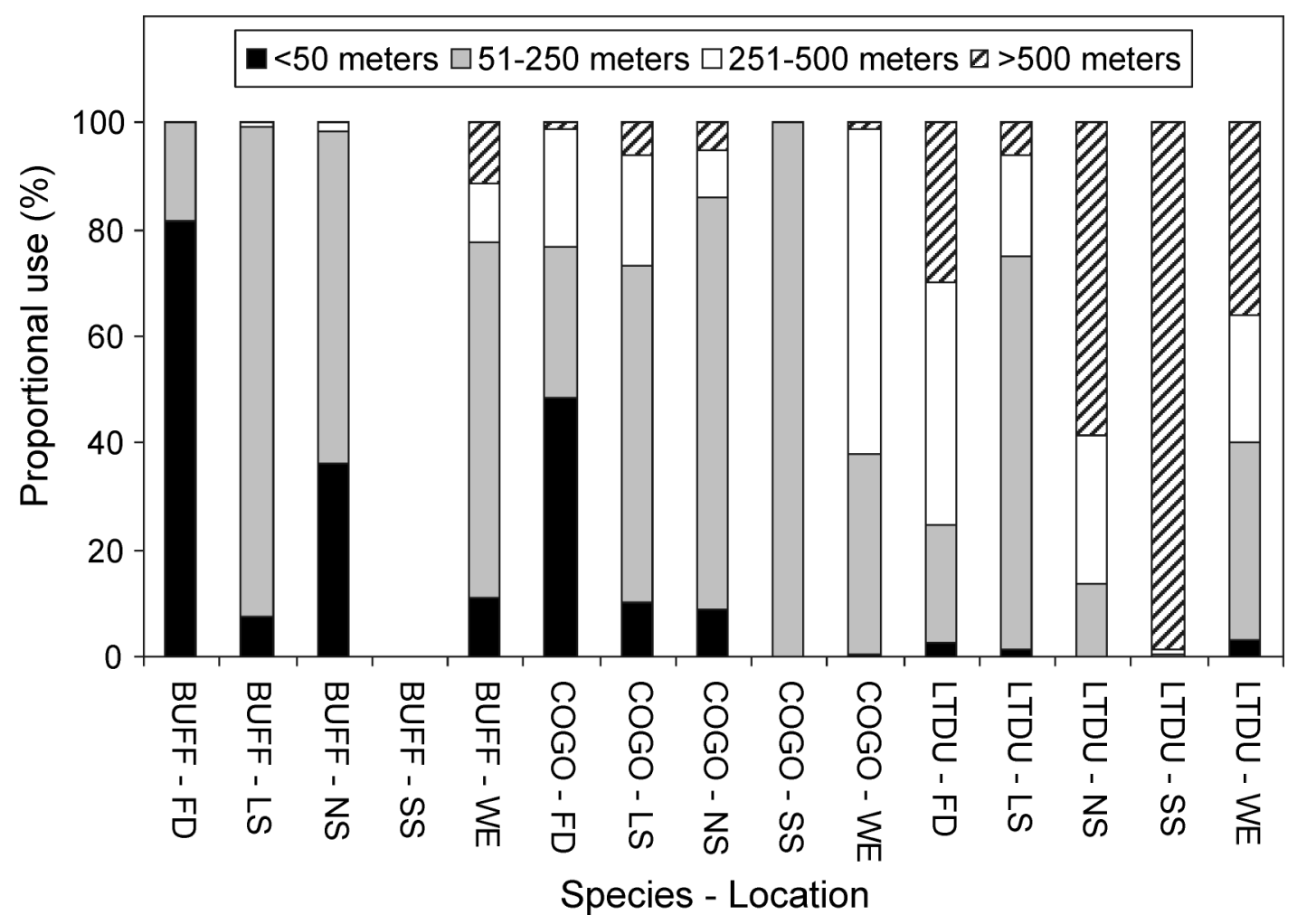

FIG. 5. Proportional use of distance categories by foraging buffleheads (BUFF), common goldeneyes (COGO) and long-tailed ducks (LTDU) along the southeast shoreline of Prince Edward County, Lake Ontario, December-March, 2002-03 and 2003-04. Abbreviations: FD = False Ducks, LS = Lake Shore, NS = North Shore, SS = South Shore, and WE = West End .

nearshore areas and limited abundance of benthic macroinvertebrates beyond $30 \mathrm{~m}$ (Barton and Hynes 1978, Barton 1986, Kilgour et al. 2000). When abiotic factors do not increase the number of nearshore macroinvertebrates, more food is available to birds that can forage in deeper water. However, during winter, shallow water areas along exposed coastlines are susceptible to wave action and, subsequently, these areas in which Amphipoda and Chironomidae accumulated also received the highest use by diving ducks. Areas with lower concentrations of macroinvertebrates (i.e., North Shore and South Shore) received less use by buffleheads, while common goldeneyes and long-tailed ducks fed in these areas but did so farther from shore. Buffleheads normally do not forage in water deeper than $3 \mathrm{~m}$ and appear to be physiologically constrained in this manner (Erskine 1971). Therefore, while food is present at depths beyond $3 \mathrm{~m}$, this food is not actually available to buffleheads. In contrast, common goldeneyes forage to $9 \mathrm{~m}$ (Olney and
Mills 1963) and long-tailed ducks have been recorded foraging as deep as $60 \mathrm{~m}$ (Schorger 1951, Ellarson 1956). Diving ability coupled with differential needs of species due to energetic costs related to body size likely explains species differences in habitat use during winter.

Common goldeneyes and long-tailed ducks normally accompanied buffleheads in nearshore areas, but the few common goldeneyes and long-tailed ducks that foraged further from shore were often found in species-specific flocks. This community structure increases the potential for interference competition for buffleheads, while common goldeneyes and long-tailed ducks can reduce competition via habitat selection. However, little aggression, territoriality (Schummer 2005), or habitat segregation among diving ducks was observed during the study, further suggesting that food was not limiting. Small-bodied birds such as buffleheads are more energetically constrained than larger waterfowl (Calder 1974) and may not have been 


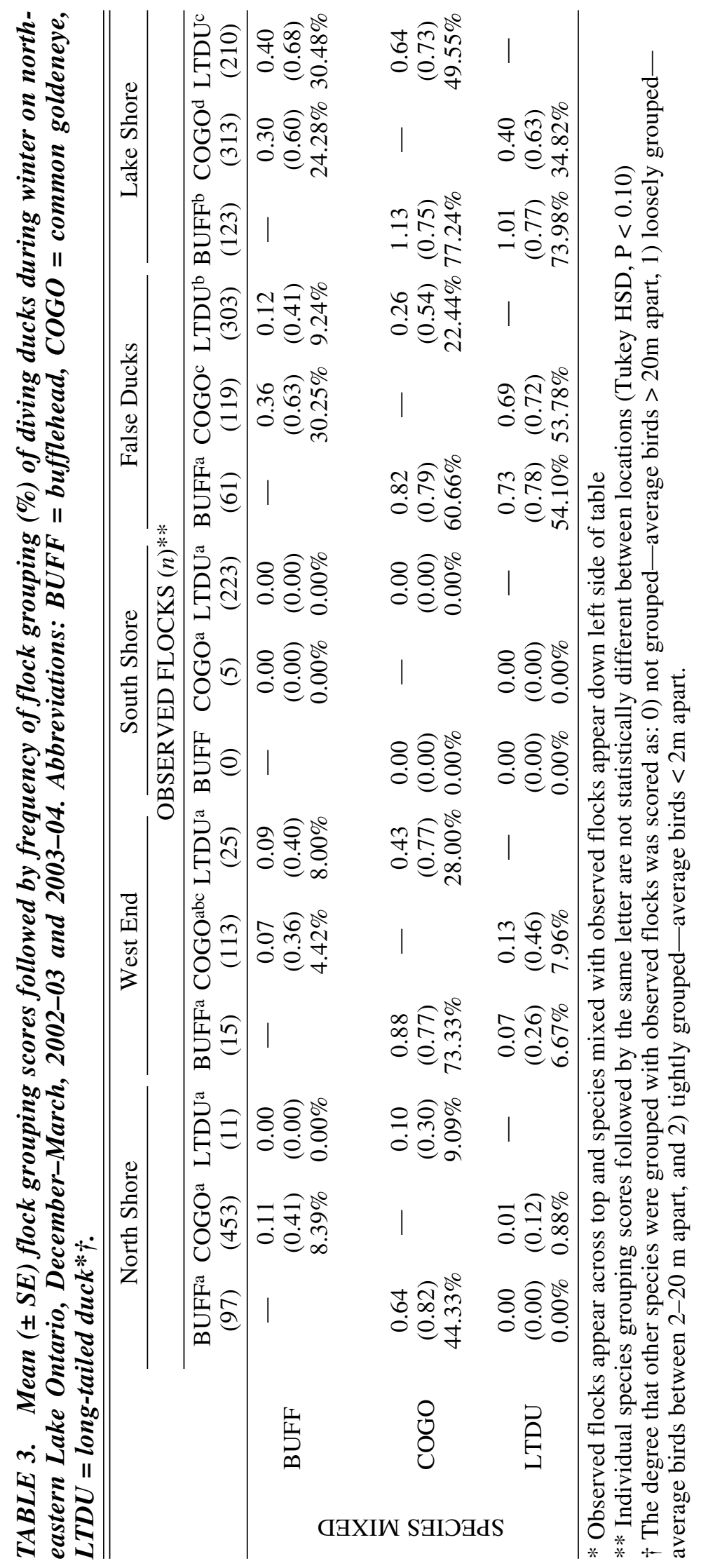


able to modify behavior to avoid mixed species flocking. Considering that food did not appear to be limiting throughout winter, it is more likely that social interactions helped buffleheads, common goldeneyes and long-tailed ducks to locate and exploit food in nearshore areas during the energetically costly winter period. Furthermore, because buffleheads remained in nearshore areas of highly abundant food, it is possible that common goldeneyes and long-tailed ducks used the presence of buffleheads as an indicator of food availability. Waterfowl often feed by local enhancement, joining other waterfowl already feeding (Hinde 1961, Pöysä 1986). Similar findings have been reported for bird communities using marine systems that exploit food near upwellings (Horn 1968, Cody 1974, Foreno et al. 2004). Our results are consistent with habitat selection and mixed species flocking behavior often associated with superabundant food resources. Community structure coupled with direct measurement of food resources suggest that food was not limiting to diving ducks on our study area. Furthermore, our results suggest that thermoregulatory costs associated with body size (Calder 1974) and differential diving ability of birds could also influence habitat selection. Our observations indicate that abiotic factors could greatly influence numbers of nearshore macroinvertebrates on northeastern Lake Ontario and this relationship requires further investigation to fully understand availability of foods to diving ducks during winter throughout the Great Lakes.

\section{ACKNOWLEDGMENTS}

Financial support was provided by the Long Point Waterfowl and Wetlands Research Fund, through funding provided by the Bluff's Hunting Club, Ducks Unlimited Canada, S.C. Johnson and Son, Ltd, Ontario Federation of Anglers and Hunters; and Natural Sciences and Engineering Research Council of Canada Research Grant awarded to R. C. Bailey. Bird Studies Canada and the Canadian Wildlife Service provided logistical support. We thank Eion Craigie, Greg Dunn, Sarah Fleming, Roxy Lancaster, Shawn Meyer, Beau Shroyer, Robert Ward Sr., Robert Ward Jr., and David Wight for field assistance. Jenna Donald, Sarah Fleming, Sarah Gil, Amanda Kosloski, Crystal LaFrance, Jen Musada, Silvia Perez, and Babak Shojaei provided laboratory assistance. Ken Abraham, Dave Ankney, Shannon Badzinski, Guy Baldassarre, Darrell Dennis, Gary MacCullough, Jack Millar, Bob
Scott, and two anonymous reviewers provided helpful comments on the manuscript.

\section{REFERENCES}

Albright, J.J. 1981. Behavioral and physiological responses of coastal-wintering black ducks (Anas rubripes) to changing weather in Maine. M. S. thesis, University of Maine, Orono.

Altman, J. 1974. Observational study of behaviour:sampling methods. Behaviour 49:227-267.

Arthur, W. 1987. The niche in competition and evolution. New York, New York: John Wiley and Sons.

Assel, R.A. 2003. Great Lakes ice cover, first ice, last ice and ice duration: winters 1973-2002. NOAA Technical Memorandum GLERL-125, Great Lakes Environmental Research Laboratory. Ann Arbor, Michigan.

Badzinski, S.S., and Petrie, S.A. 2006. Lesser scaup pring nutrient reserve dynamics on the Lower Great Lakes. Wildlife Society Bulletin 34:395-407.

Barton, D.R. 1986. Nearshore benthic invertebrates of the Ontario waters of Lake Ontario. J. Great Lakes Res. 12:270-280.

and Griffiths, M. 1984. Benthic macroinvertebrates of the nearshore zone of eastern Lake Huron, Georgian Bay and North Channel. J. Great Lakes Res. 10:407-416.

and Hynes, H.B.N. 1978. Wave-zone macrobenthos of the exposed Canadian shores of the St. Lawrence Great Lakes. J. Great Lakes Res. 4:27-45.

Bellrose, F.C. 1980. Ducks, geese and swans of North America. Harrisburg, PA: Stackpole Books.

Calder, W.A. 1974. The consequences of body size for avian energetics. In Avian energetics, R.A. Paynter, ed., pp. 86-151. Cambridge, MA: Nuttall Ornitholigical Club.

Cody, M.L. 1974. Competition and the structure of bird communities. Princeton University Press.

Custer, C.M., and Custer, T.W. 1996. Food habits of diving ducks in the Great Lakes after the zebra mussel invasion. J. Field Ornith. 67:86-99.

Dermott, R., Mitchell, J., Murray, W., and Fear, E. 1993. Biomass and production of zebra mussels Dreissena polymorpha in shallow waters of northeastern Lake Erie. In Zebra mussels, biology, impacts and control, T.F. Nalepa and D.W. Schoesser, eds., pp. 399-414. Boca Raton, Florida: CRC Press.

Diamond, J.M. 1978. Niche shifts and the rediscovery of interspecific competition. Am. Scientist 66:322-331.

Ellarson, R.S. 1956. A study of the Old-squaw Duck on Lake Michigan. Ph.D. thesis. University of Wisconsin, Madison.

Erskine, A.J. 1971. Buffleheads. Canadian Wildlife Service, Monographs Series Number 4, Information Canada, Ottawa. 
Foreno, M.G., Bortolotti, G.R., Hobson, K.A.. Donazar, J.A, Bertelloti, M. and Blanco, G. High trophic overlap within seabird community of Argentinean Patagonia: a multiscale approach. J. Animal Ecol. 73:789-801.

Golikov, A.N., and Scarlato, O.A. 1973. Comparative characteristics of some ecosystems of the upper region of the shelf in tropical, temperate and Arctic waters. Helgol. Wiss. Meeresunters 24:219-234.

Gonzalez, M.J., and Downing, A. 1999. Mechanism underlying amphipod responses to zebra mussel (Dreissena polymorpha) invasion and implications for fish-amphipod interactions. Can. J. Fish. Aquat. Sci. 56:679-685.

Goudie, R.I., and Ankney, C.D. 1986. Body size, activity budgets, and diets of seas ducks wintering in Newfoundland. Ecology 67:1475-1482.

Guillemette, M., Himmelen, J.H., Barette, C., and Reed, A. 1993. Habitat selection by common eiders in winter and its interaction with flock size. Can. J. Zool. 71:1259-1266.

Hamilton D.A., and Ankney, C.D. 1994. Consumption of zebra mussels Dreissena polymorpha by diving ducks in Lakes Erie and St. Clair. Wildfowl 45:159-166.

, Ankney, C.D., and Bailey, R. C. 1994. Predation of zebra mussels by diving ducks: An exclosure study. Ecology 73:521-531.

Hinde, R.A. 1961. Behaviour. In Biology and comparative physiology of birds, A.J. Marshall, ed. London, UK: Academic Press.

Horn, H.S. 1968. The adaptive significance of colonial nesting in the Brewer's Blackbird (Eaphagus cyanocephalus). Ecology 49:682-694.

Jansson, A., and Kautsky, N. 1977. Quantitative survey of hard bottom communities in the Baltic archipelago. Eleventh European Symposium of Marine Biology, 1976, Galway.

Jones, J.J., and Drobney, R.D. 1986. Winter feeding ecology of scaup and common goldeneye in Michigan. J. Wildl. Manage. 50:446-452.

Keddy, P.A. 1989. Competition. London: Chapman and Hall.

Kilgour, B.W., Bailey, R.C., and Howell, E.T. 2000. Factors influencing changes in the nearshore benthic community on the Canadian side of Lake Ontario. $J$. Great Lakes Res. 26:272-286.

King, R.S., and Richardson, C.J. 2002. Evaluating subsampling approaches and macro invertebrate taxonomic resolution for wetland bioassessment. J. NA Benth. Soc. 21: 150-171.

Krebs, C.J., and Davies, N.B. 1991. Behavioural ecology: An evolutionary approach, $3^{\text {rd }}$ ed. Oxford: Blackwell Scientific Publications.

Krecker, F.H., and Lancaster, L.Y. 1933. Bottom shore fauna of western Lake Erie: a population study to a depth of six feet. Ecology 14:79-93.
Kuhns, L.A., and Berg, M.B. 1999. Benthic invertebrate community response to round goby (Neogobius melanostromus) and zebra mussel (Dreissena polymorpha) invasion in southern Lake Michigan. $J$. Great Lakes Res. 25:910-917.

Lima, S.L. 1986. Predation risk and unpredictable feeding conditions: determinants of body mass in birds. Ecology 67:377-385.

Lovvorn, J.R. 1989. Food dependability and antipredator tactics: implications for dominance and pairing in Canvasbacks. Condor 91:826-836.

MacArthur, R.H., and Levins, R. 1967. The limiting similarity, convergence and divergence of coexisting species. Am. Natural. 101:377-385.

Madsen, J. 1995. Impacts of disturbance on migratory waterfowl. Ibis 137:567-574.

Marsh, C.P. 1986. Rocky intertidal community organization:the impact of avian predators on mussel recruitment. Ecology 67:771-786.

Mayr, E. 1970. Populations, Species, and Evolution. Belknap Press, Harvard University Press.

Mitchell, C.A., Bailey, R.C., and Knapton, R.W. 2000. Effects of predation by fish and wintering ducks on dreissenid mussels at Nanticoke, Lake Erie. Ecoscience 7:389-409.

Nalepa, T.F., and Robertson, A. 1981. Vertical distribution of the zoobenthos in southeastern Lake Michigan with evidence of seasonal variation. Freshwater Biol. 11:87-96.

Nilsson, L. 1972. Local distribution, food choice, and food consumption of diving ducks on a South Sweden lake. Oikos 23:82-91.

Olney, P.J.S., and Mills, D.H. 1963. The food and feeding habits of goldeneye (Bucephala clangula) in Great Britain. Ibis 105:293-300.

Owen, N.W. 1977. Responses of wintering brent geese to human disturbance. Wildfowl 28:5-14.

Owen, R.B., Jr., and Reinecke, K.J. 1979. Bioenergetics of breeding dabbling ducks. In Waterfowl and wetlands-an integrated review, T.A. Bookhout, ed., pp. 71-93. Madison, Wisconsin, North Central Section of the Wildlife Society.

Pedroli, J.C. 1981. Les relations entre la moule zébréé Dreissena polymorpha (Pallas) et les oiseaux aquatiques. Diss., Univ. de Neuchâtel, Neuchâtel, Switzerland.

Perhsson, O. 1976. Food and feeding grounds of the goldeneye Bucephala clangula, on the Swedish west coast. Ornis Scandinavia 7:91-112.

Petrie, S.A., and Knapton, R.W. 1999. Rapid increase and subsequent decline of zebra and quagga mussels in Long Point Bay, Lake Erie; possible influence of waterfowl predation. J. Great Lakes Res. 25:772-782. and Schummer, M.L. 2002. Waterfowl response to zebra mussels on the Lower Great Lakes. Birding $34: 346-351$. 
Phillips, V.E. 1991. Pochard Aythya ferina use of chironomid-rich feeding habitat in winter. Bird Study 38:118-122.

Poulton, V.K., Lovvorn, J.R., and Takekawa, J.Y. 2002. Clam density and scaup feeding behavior in San Pablo Bay, California. Condor 104:518-527.

Pöysä, H. 1986. Foraging niche shifts in multispecies dabbling duck (Anas spp.) feeding groups: harmful and beneficial interactions between species. Ornis Scandinavica 17:333-346.

Prince, H.H. 1979. Bioenergetics of postbreeding dabbling ducks. In Waterfowl and wetlands-an integrated review, T.A. Bookhout, ed., pp. 101-107. Madison, Wisconsin: North Central Section of the Wildlife Society.

Quinlan, E.E., and Baldassarre, G.A. 1984. Activity budgets of nonbreeding Green-winged Teal on playa lakes in Texas. J. Wildl. Manage. 48:838-845.

Ross, R.K., Petrie, S.A., Badzinski, S.S., and Mullie, A. 2005. Autumn diets of greater scaup, lesser scaup, and long-tailed ducks on eastern Lake Ontario prior to zebra mussel invasion. Wildl. Soc. Bull. 33:81-91.

SAS Institute Inc. 1990. SAS/STAT user's guide, version $6,4^{\text {th }}$ ed. SAS Institute Inc., Cary, North Carolina.

Schoener, T.W. 1974. Resource partitioning in ecological communities. Science 185:27-39.

Schorger, A.W. 1951. Deep diving of the Oldsquaw. Wilson Bull. 63:112.

Schummer, M.L. 2005. Resource use by diving ducks during winter on northeastern Lake Ontario. Ph.D. dissertation, University of Western Ontario, London, Ontario.

, Petrie, S.A., and Bailey, R.C. 2008. Dietary overlap of sympatric diving ducks during winter on northeastern Lake Ontario. Auk: In Press.

Sekiya, Y., Hiratsuka, J., Yamamuro, M., Oka, N., and Aba, M. 2000. Diet selectivity and shift of wintering common pochards and tufted ducks in a eutrophic coastal lagoon. J. Marine Syst. 26:233-238.

Stewart, T.W., and Haynes, J.M. 1994. Benthic macroinvertebrate communities of southwestern Lake Ontario following invasion by Dreissena. J. Great Lakes Res. 20:479-493.

Stott, R.S., and Olson, D.P. 1973. Food habitat relation- ships of sea ducks on the New Hampshire coastline. Ecology 54:996-1007.

Suter, W. 1982a. Die Bedeutung von Untersee-Ende/ Hochrhein (Bodensee) als wichtiges Überwinter-ungsgewässer für Tauchenten (Aythya, Bucephala) und Blässhuhn (Fulica atra). Der Ornithologische Beobachter 79:73-96.

1982b. Veliechende Nahrungsökologie von überwinterden Tauchenten (Aythya, Bucephala) und Blässhuhn (Fulica atra) am Untersee-Ende/Hochrein (Bodensee). Der Ornithologische Beobachter 79:225-254.

1982c. Der Einfluss von Wasservögeln auf Populationen der Wandermuschel (Dreissena polymorpha Pall.) am Untersee/Hochrhein (Bodensee). Schweizerische Zeitschrift fuer Hydrologie 44:149-161.

and Van Eerden, M. R. 1992. Simultaneous mass starvation of wintering diving ducks in Switzerland and the Netherlands:A wrong decision in the right strategy? Adrea 80:229-242.

Thorp, J.H., and Covich, A.P. 1991. Ecology and classification of North American freshwater invertebrates. New York, New York: Academic Press.

Wiens, J.A. 1977. On competition and variable environments. American Scientist 65:590-597.

Wisenden, P.A., and Bailey, R.C. 1995. Development of macroinvertebrate community structure associated with zebra mussel (Dreissena polymorpha) colonization of artificial substrates. Can. J. Zool. 73:1438-1443.

Woakes, A.J., and Butler, P.J. 1983. Swimming and diving in tufted ducks, Aythya fuliga, with particular reference to heart rate and gas exchange. J. Exper. Biol. 107:311-329.

Wormington, A., and Leech, J.H. 1992. Concentrations of diving ducks at Point Pelee, Ontario, in response to invasion of zebra mussels, Dreissena polymorpha. Can. Field Natural. 106:376-380.

Ydenburg, R.C., and Guillemette, M. 1991. Diving and foraging in the common eider. Ornis Scandinavia $22: 349-352$.

Submitted: 1 September 2006

Accepted: 24 October 2007

Editorial handling: Martin A. Stapanian 
APPENDIX 1. Factors influencing numbers of macroinvertebrates during late-October and April, 2002-03 and 2003-04, at Prince Edward Bay, Lake Ontario; Y = Year, S = Season, D = Depth, L = Location.

\begin{tabular}{|c|c|c|c|c|c|c|}
\hline \multirow[b]{2}{*}{ Taxon $_{\mathrm{df}}$} & \multirow[b]{2}{*}{ Model $_{\mathrm{df}}$} & \multirow[b]{2}{*}{$\mathrm{R}^{2}$} & \multirow[b]{2}{*}{$\mathrm{F}$} & \multirow[b]{2}{*}{$\mathrm{P}$} & \multicolumn{2}{|c|}{ Mean (SE) } \\
\hline & & & & & Fall & Spring \\
\hline \multicolumn{7}{|l|}{ Mollusca } \\
\hline \multicolumn{7}{|l|}{ Gastropoda 18,125} \\
\hline & $\mathrm{Y} \times \mathrm{D}_{2}$ & 0.03 & 2.80 & 0.0644 & \multirow{7}{*}{$\begin{array}{l}232.47 \\
(49.01)\end{array}$} & \multirow{7}{*}{$\begin{array}{l}148.49 \\
(70.24)\end{array}$} \\
\hline & $\mathrm{S} \times \mathrm{L}_{3}$ & 0.04 & 2.87 & 0.0389 & & \\
\hline & $\mathrm{D} \times \mathrm{L}_{6}$ & 0.14 & 5.14 & $<0.0001$ & & \\
\hline & Year $_{1}$ & 0.01 & 2.06 & 0.1541 & & \\
\hline & Season $_{1}$ & 0.06 & 14.49 & 0.0002 & & \\
\hline & Depth $_{2}$ & 0.11 & 12.23 & $<0.0001$ & & \\
\hline & Location $_{3}$ & 0.03 & 2.56 & 0.0580 & & \\
\hline \multirow[t]{7}{*}{ Valvatidae 27,116} & $\mathrm{Y} \times \mathrm{D} \times \mathrm{L}_{11}$ & 0.08 & 2.03 & 0.0317 & \multirow{7}{*}{$\begin{array}{l}101.96 \\
(35.74)\end{array}$} & \multirow{7}{*}{$\begin{array}{c}89.56 \\
(63.19)\end{array}$} \\
\hline & $\mathrm{S} \times \mathrm{L}_{3}$ & 0.03 & 3.01 & 3.0332 & & \\
\hline & $\mathrm{D} \times \mathrm{L}_{6}$ & 0.17 & 8.17 & $<0.0001$ & & \\
\hline & Year $_{1}$ & 0.01 & 1.77 & 0.1855 & & \\
\hline & Season $_{1}$ & 0.03 & 7.92 & 0.0058 & & \\
\hline & Depth $_{2}$ & 0.03 & 8.16 & 0.0005 & & \\
\hline & Location $_{3}$ & 0.22 & 21.17 & $<0.0001$ & & \\
\hline \multirow[t]{6}{*}{ Hydrobiidae 12,131} & $\mathrm{~S} \times \mathrm{L}_{3}$ & 0.07 & 4.72 & 0.0037 & \multirow{6}{*}{$\begin{array}{c}81.50 \\
(15.87)\end{array}$} & \multirow{6}{*}{$\begin{array}{c}59.89 \\
(22.54)\end{array}$} \\
\hline & $\mathrm{S} \times \mathrm{D}_{2}$ & 0.02 & 2.39 & 0.0953 & & \\
\hline & Year $_{1}$ & 0.05 & 9.74 & 0.0022 & & \\
\hline & Season $_{1}$ & 0.03 & 6.04 & 0.0153 & & \\
\hline & Depth $_{2}$ & 0.12 & 11.23 & $<0.0001$ & & \\
\hline & Location $_{3}$ & 0.05 & 3.04 & 0.0312 & & \\
\hline \multirow[t]{7}{*}{ Pleuroceridae $_{25,118}$} & $\mathrm{~S} \times \mathrm{D} \times \mathrm{L}_{11}$ & 0.14 & 2.93 & 0.0019 & \multirow{7}{*}{$\begin{array}{c}2.41 \\
(0.81)\end{array}$} & \multirow{7}{*}{$\begin{array}{c}3.49 \\
(1.17)\end{array}$} \\
\hline & $\mathrm{Y} \times \mathrm{S}_{1}$ & 0.02 & 4.50 & 0.0360 & & \\
\hline & $\mathrm{D} \times \mathrm{L}_{6}$ & 0.08 & 3.05 & 0.0082 & & \\
\hline & Year ${ }_{10}$ & 0.01 & 2.56 & 0.1119 & & \\
\hline & Season $_{1}$ & 0.01 & 2.69 & 0.1039 & & \\
\hline & Depth $_{2}$ & 0.15 & 17.09 & $<0.0001$ & & \\
\hline & Location $_{3}$ & 0.11 & 8.52 & $<0.0001$ & & \\
\hline \multirow[t]{3}{*}{ Lymnaeidae $_{11,132}$} & $\mathrm{D} \times \mathrm{L}_{6}$ & 0.14 & 3.88 & 0.0014 & \multirow{3}{*}{$\begin{array}{l}10.15 \\
(5.04)\end{array}$} & \multirow{3}{*}{$\begin{array}{c}4.38 \\
(1.88)\end{array}$} \\
\hline & Depth $_{2}$ & 0.03 & 2.34 & 0.1002 & & \\
\hline & Location $_{3}$ & 0.05 & 2.97 & 0.0343 & & \\
\hline \multirow[t]{9}{*}{ Physidae $_{19,124}$} & $\mathrm{Y} \times \mathrm{S} \times \mathrm{L}_{3}$ & 0.06 & 5.00 & 0.0026 & \multirow{9}{*}{$\begin{array}{l}12.00 \\
(3.10)\end{array}$} & 1.72 \\
\hline & $\mathrm{Y} \times \mathrm{S}_{1}$ & 0.02 & 559 & 0.0197 & & \\
\hline & $\mathrm{Y} \times \mathrm{L}_{3}$ & 0.06 & 5.07 & 0.0024 & & \\
\hline & $\mathrm{Y} \times \mathrm{D}_{2}$ & 0.03 & 3.93 & 0.0221 & & \\
\hline & $\mathrm{S} \times \mathrm{L}_{3}$ & 0.03 & 2.37 & 0.0742 & & \\
\hline & Year $_{1}$ & 0.00 & 0.01 & 0.9393 & & \\
\hline & Season $_{1}$ & 0.09 & 21.90 & $<0.0001$ & & \\
\hline & Depth $_{2}$ & 0.00 & 0.50 & 0.6092 & & \\
\hline & Location $_{3}$ & 0.06 & 5.10 & 0.0023 & & \\
\hline
\end{tabular}


APPENDIX 1. (Continued).

\begin{tabular}{|c|c|c|c|c|c|c|}
\hline \multirow[b]{2}{*}{ Taxon $_{\mathrm{df}}$} & \multirow[b]{2}{*}{ Model $_{\mathrm{df}}$} & \multirow[b]{2}{*}{$\mathrm{R}^{2}$} & \multirow[b]{2}{*}{$\mathrm{F}$} & \multirow[b]{2}{*}{$\mathrm{P}$} & \multicolumn{2}{|c|}{ Mean (SE) } \\
\hline & & & & & Fall & Spring \\
\hline \multirow[t]{5}{*}{ Planorbidae $_{8,135}$} & $\mathrm{Y} \times \mathrm{S}_{1}$ & 0.05 & 7.83 & 0.0059 & \multirow[t]{5}{*}{$\begin{array}{l}15.41 \\
(4.94)\end{array}$} & \multirow[t]{5}{*}{$\begin{array}{c}7.28 \\
(2.93)\end{array}$} \\
\hline & Year $_{1}$ & 0.02 & 3.56 & 0.0612 & & \\
\hline & Season $_{1}$ & 0.00 & 0.55 & 0.4594 & & \\
\hline & Depth $_{2}$ & 0.04 & 3.04 & 0.0510 & & \\
\hline & Location $_{3}$ & 0.07 & 3.97 & 0.0096 & & \\
\hline \multicolumn{7}{|l|}{ Bivalvia } \\
\hline \multirow[t]{5}{*}{ Dreissenid $_{23,120}$} & $\mathrm{~S} \times \mathrm{D} \times \mathrm{L}_{11}$ & 0.07 & 1.87 & 0.0495 & \multirow[t]{5}{*}{$\begin{array}{l}3260.30 \\
(560.93)\end{array}$} & \multirow[t]{5}{*}{$\begin{array}{c}5960.06 \\
(2173.08)\end{array}$} \\
\hline & $\mathrm{D} \times \mathrm{L}_{6}$ & 0.21 & 9.63 & $<0.0001$ & & \\
\hline & Season $_{1}$ & 0.00 & 0.49 & 0.4845 & & \\
\hline & Depth $_{2}$ & 0.25 & 34.03 & $<0.0001$ & & \\
\hline & Location $_{3}$ & 0.03 & 2.72 & 0.0474 & & \\
\hline \multicolumn{7}{|l|}{ Insecta } \\
\hline \multirow[t]{7}{*}{ Trichoptera 26, 117} & $\mathrm{Y} \times \mathrm{D} \times \mathrm{L}_{11}$ & 0.10 & 1.99 & 0.0349 & \multirow[t]{7}{*}{$\begin{array}{c}8.74 \\
(3.09)\end{array}$} & \multirow[t]{7}{*}{$\begin{array}{c}2.42 \\
(0.64)\end{array}$} \\
\hline & $\mathrm{S} \times \mathrm{D}_{2}$ & 0.03 & 3.49 & 0.0336 & & \\
\hline & $\mathrm{D} \times \mathrm{L}_{6}$ & 0.09 & 3.28 & 0.0051 & & \\
\hline & Year $_{1}$ & 0.03 & 5.45 & 0.0213 & & \\
\hline & Season $_{1}$ & 0.01 & 2.07 & 0.1527 & & \\
\hline & Depth $_{2}$ & 0.10 & 11.00 & $<0.0001$ & & \\
\hline & Location $_{3}$ & 0.07 & 5.18 & 0.0021 & & \\
\hline \multicolumn{7}{|l|}{ Diptera } \\
\hline \multirow[t]{5}{*}{ Chironomidae 13,130} & $\mathrm{D} \times \mathrm{L}_{6}$ & 0.06 & 2.38 & 0.0324 & \multirow[t]{5}{*}{$\begin{array}{c}78.87 \\
(24.18)\end{array}$} & \multirow[t]{5}{*}{$\begin{array}{l}216.02 \\
(55.65)\end{array}$} \\
\hline & Year $_{1}$ & 0.08 & 18.79 & $<0.0001$ & & \\
\hline & Season $_{1}$ & 0.06 & 13.99 & 0.0003 & & \\
\hline & Depth $_{2}$ & 0.12 & 13.54 & $<0.0001$ & & \\
\hline & Location $_{3}$ & 0.05 & 3.39 & 0.0200 & & \\
\hline \multicolumn{7}{|l|}{ Crustacea } \\
\hline \multirow[t]{7}{*}{ Amphipoda 19,124} & $\mathrm{Y} \times \mathrm{L}_{3}$ & 0.04 & 3.30 & 0.0226 & \multirow[t]{7}{*}{$\begin{array}{c}430.19 \\
(100.15)\end{array}$} & \multirow[t]{7}{*}{$\begin{array}{c}122.28 \\
(24.56)\end{array}$} \\
\hline & $\mathrm{S} \times \mathrm{L}_{3}$ & 0.16 & 14.12 & $<0.0001$ & & \\
\hline & $\mathrm{D} \times \mathrm{L}_{6}$ & 0.10 & 4.35 & 0.0005 & & \\
\hline & Year $_{1}$ & 0.00 & 0.17 & 0.6824 & & \\
\hline & Season $_{1}$ & 0.10 & 25.47 & $<0.0001$ & & \\
\hline & Depth $_{2}$ & 0.06 & 7.84 & $<0.0006$ & & \\
\hline & Location $_{3}$ & 0.11 & 9.24 & $<0.0001$ & & \\
\hline \multirow[t]{2}{*}{ Isopoda 5,138} & Depth $_{2}$ & 0.16 & 14.87 & $<0.0001$ & \multirow{2}{*}{$\begin{array}{l}11.38 \\
(4.65)\end{array}$} & 10.17 \\
\hline & Location $_{3}$ & 0.07 & 4.51 & 0.0048 & & \\
\hline
\end{tabular}

